University of Nebraska - Lincoln

DigitalCommons@University of Nebraska - Lincoln

Publications, Agencies and Staff of the U.S.

Department of Commerce

U.S. Department of Commerce

2010

\title{
Lake Michigan lower food web: Long-term observations and Dreissena impact
}

\author{
G. Fahnenstiel \\ National Oceanic and Atmospheric Administration, gary.fahnenstiel@noaa.gov \\ T. Nalepa \\ National Oceanic and Atmospheric Administration, thomas.nalepa@noaa.gov \\ S. Pothoven \\ National Oceanic and Atmospheric Administration, steve.pothoven@noaa.gov \\ H. Carrick \\ Pennsylvania State University - Main Campus, hjc11@psu.edu \\ D. Scavia \\ University of Michigan - Ann Arbor, scavia@umich.edu
}

Follow this and additional works at: https://digitalcommons.unl.edu/usdeptcommercepub

Part of the Environmental Sciences Commons

Fahnenstiel, G.; Nalepa, T.; Pothoven, S.; Carrick, H.; and Scavia, D., "Lake Michigan lower food web: Longterm observations and Dreissena impact" (2010). Publications, Agencies and Staff of the U.S. Department of Commerce. 403.

https://digitalcommons.unl.edu/usdeptcommercepub/403

This Article is brought to you for free and open access by the U.S. Department of Commerce at DigitalCommons@University of Nebraska - Lincoln. It has been accepted for inclusion in Publications, Agencies and Staff of the U.S. Department of Commerce by an authorized administrator of DigitalCommons@University of Nebraska - Lincoln. 


\title{
Lake Michigan lower food web: Long-term observations and Dreissena impact
}

\author{
G. Fahnenstiel ${ }^{\text {a,* }}$, T. Nalepa ${ }^{\text {b }}$, S. Pothoven ${ }^{\text {a }}$, H. Carrick ${ }^{\text {c }}$, D. Scavia ${ }^{d}$ \\ a Lake Michigan Field Station/Great Lakes Environmental Research Laboratory/NOAA, 1431 Beach St, Muskegon, MI 49441, USA \\ b Great Lakes Environmental Research Laboratory/NOAA, 4840 S. State Rd., Ann Arbor, MI 48108, USA \\ c School Forest Resources, Pennsylvania State University, 434 Forest Resources Building, University Park, PA 16802, USA \\ d School of Natural Resources and Environment, University of Michigan, 440 Church St., Ann Arbor, MI 48109, USA
}

\section{A R T I C L E I N F O}

\section{Article history:}

Received 6 April 2010

Accepted 29 April 2010

Communicated by Joseph Makarewicz

\section{Keywords:}

Food web

Phytoplankton

Zooplankton

Phosphorus

\begin{abstract}
A B S T R A C T
Lake Michigan has a long history of non-indigenous introductions that have caused significant ecological change. Here we present a summary of eight papers that document recent changes and the current state of the lower food web of southern Lake Michigan after the establishment of large dreissenid populations. Results are based on long-term data sets collected by federal and academic research and monitoring programs that place recent changes into a historic context. Dramatic and significant changes in the lower food web, such as the loss of the spring diatom bloom, large declines in phytoplankton productivity, and a decline of Mysis populations, were directly or indirectly attributed to the expansion of Dreissena rostriformis bugensis. Total phosphorus concentrations and loadings also have decreased in the last 20 years. Changes in the Lake Michigan ecosystem induced by $D$. $r$. bugensis have produced conditions in the offshore pelagic region that are similar to oligotrophic Lake Superior. The future state of the lower food web in southern Lake Michigan is difficult to predict, mainly because population trends of D.r. bugensis in cold, offshore regions are unknown. Hence, monitoring programs designed to collect long-term, consistent data on the lower food web of Lake Michigan are essential.
\end{abstract}

Published by Elsevier B.V.

\section{Introduction}

Our ability to understand, predict, and manage an environment depends on the collection of consistent, long-term data because changes in important ecological properties and processes occur mostly over a period of decades or longer (Magnuson, 1990). Longterm data allow us to understand the present state of an ecosystem, to place this state into a chronological framework, and to predict future trends (Hobbie et al., 2003). Without this longer-term temporal context, management strategies can be misguided and ultimately costly to society (Magnuson, 1990).

Ecological changes in large, complex ecosystems like the Great Lakes occur at different rates depending on the ecosystem component and the particular stressor driving that change. That is, ecological responses to global warming occur over more deliberate time periods than responses to invasive species. Long-term data sets define these rates relative to natural ecological variation that can, for instance, be induced by weather events or intrinsic population cycles (Scavia et al., 1986; Madenjian et al., 2006). Lake Michigan has a long history of ecological change that has been documented with long-term data sets. Over the past 30-40 years, the primary drivers of change have

\footnotetext{
* Corresponding author. Tel.: +1231759 7824 .

E-mail addresses: gary.fahnenstiel@noaa.gov (G. Fahnenstiel), thomas.nalepa@noaa.gov (T. Nalepa), steve.pothoven@noaa.gov (S. Pothoven), hjc11@psu.edu (H. Carrick), scavia@umich.edu (D. Scavia).
}

been nutrient loads and invasive species, and all major food web components have been affected (Madenjian et al., 2002).

In this special issue of the Journal of Great Lakes Research, we present results from federal and academic research and monitoring programs that together provide a holistic and temporal framework for examining recent unprecedented changes in the Lake Michigan food web. Most of the papers present results of monitoring programs established by National Oceanic and Atmospheric Administration's (NOAA) Great Lakes Environmental Research Laboratory which spanned nearly three decades. While there are temporal gaps in these programs, long-term continuity and consistency in sample collection make these data invaluable in assessing recent changes in the Lake Michigan lower food web. While the NOAA program focused on one region of southern Lake Michigan, Mida et al. (2010) using data from the U.S. Environmental Protection Agency's (EPA) monitoring program, and Kerfoot et al. (2010), using satellite observations, provide convincing evidence that conditions from the NOAA monitoring sites are representative of the entire southern basin.

During the past two to three decades, the Lake Michigan ecosystem, as well as those of the other Great Lakes, has been invaded by a variety of non-indigenous species that have significantly altered the lower food web (e.g., Mills et al., 1993; Nalepa and Fahnenstiel, 1995; Vanderploeg et al., 2002). The most significant introduction during this time frame has been the establishment of dreissenid mussels, both zebra (Dreissena polymorpha) and quagga mussels (Dreissena rostriformis bugensis). D. polymorpha mussels were first observed in Lake Michigan in the 
late 1980s and by the early/mid 1990s had established large populations in the nearshore region. D. r. bugensis was not found in Lake Michigan until 1997, but within 10 years it became the dominant mussel, replacing $D$. polymorpha in nearshore regions and establishing large populations offshore (Nalepa et al., 2009). Thus, results from longterm monitoring programs over the past few decades provide a basis for assessing the impact of this Dreissena invasion on the lower food web of Lake Michigan. This special issue documents those impacts and describes the present state of the Lake Michigan lower food web.

In the first paper of this special issue, Nalepa et al. (2010) provide a temporal framework for observed changes in the lower food web by documenting changes in abundance, biomass, size structure, and nutritional states of dreissenid populations. In addition to replacing $D$. polymorpha as the dominant mussel, D. r. bugensis has colonized offshore regions where $D$. polymorpha was never found. This expansion offshore ( $>50 \mathrm{~m}$ ) began in 2005 and appears to be occurring more rapidly in Lake Michigan than in other Great Lakes where D. $r$. bugensis populations were established earlier. Nalepa et al. (2010) also noted that $D$. r. bugensis had higher tissue mass and less shell weight per unit shell length than $D$. polymorpha. This suggests that under similar environmental conditions, $D$. $r$. bugensis allocates greater energy to tissue mass compared to $D$. polymorpha allowing it to better survive low food conditions like those in Lake Michigan.

The next three papers in this special issue document unprecedented changes in the pelagic region of southern Lake Michigan that have occurred in the last few years (Fahnenstiel et al., 2010; Kerfoot et al., 2010; Mida et al., 2010). These remarkable changes were primarily confined to the isothermally mixed late winter/spring period. Fahnenstiel et al. (2010) documented large decreases (66-87\%) in offshore phytoplankton abundance and productivity in 2007-2008 as compared to 1995-1998 and 1983-1987. The large spring diatom bloom, which played an important role in sustaining secondary production (Gardner et al., 1990), is now gone. During the mid/late thermally stratified periods (typically July-December), only one minor change was noted in phytoplankton abundance and production between the 1980s and 2007-2008 (mid stratification primary production in 2007-2008 was 22\% lower than in 1983-1987 and 1995-1998). Using a combination of remote sensing and ship observations, Kerfoot et al. (2010) extended the observations of Fahnenstiel et al. (2010) into the late winter period and to the entire southern basin. They documented a large decrease in chlorophyll and an increase in transparency in the offshore region and in the "donut rings" feature (Kerfoot et al., 2008) as compared to 2001. Kerfoot et al. (2010) also documented a shift in zooplankton community structure in this late winter/early spring period, as cyclopoid copepods and large omnivorous calanoid copepod species decreased in 2007/2008. Mida et al. (2010) analyzed long-term water quality trends from both Environmental Protection Agency (EPA) and NOAA data collected in the southern basin during the past three decades. These two monitoring programs provided complementary data; NOAA's program provided detailed temporal resolution at just one or two sites, whereas EPA's program provided broader spatial coverage but limited temporal resolution. Despite differences in methods and sampling locations between the two programs, long-term trends were evident and consistent. Spring total phosphorus and chlorophyll concentrations exhibited significant declines in the last 30 years with the most precipitous declines since 2005 . Summer total P declined slightly over the past 30 years but not summer chlorophyll. Total phosphorus loads to the southern basin decreased during the 30-year period but were not correlated with changes in spring or summer total phosphorus or chlorophyll concentrations. Water column silica and nitrate concentrations increased, consistent with a reduction in utilization by phytoplankton. The large reductions in silica and nitrate utilization ( $57 \%$ and $42 \%$, respectively) suggest that the reduction in phytoplankton production noted by Fahnenstiel et al. (2010) for the NOAA stations has occurred throughout the entire southern basin.
These recent changes in water quality and phytoplankton parameters during the late winter/spring period were caused by the filtering activities of dreissenid mussels, notably D. r. bugensis. Arguments supporting this conclusion were made to various degrees in each of the three papers (Fahnenstiel et al., 2010; Mida et al., 2010; Kerfoot et al., 2010) and can be summarized as follows. First, almost all of the significant changes occurred after 2005, which is consistent with the establishment of large populations of $D$. r. bugensis (Nalepa et al., $2009,2010)$. Second, the seasonal aspect of the changes is heuristically linked to $D$. r. bugensis. Almost all of the changes occurred during the late winter/spring period, and this is the only time of the year when bottom-dwelling mussels have a direct connection to the entire water column. During this period of the year (normally January into May), the water column is typically isothermal and well-mixed as indicated by numerous CTD profiles and current meter observations (Beletsky and Schwab, 2001; N. Hawley, GLERL, 2010 pers. comm.). Thus, at this time of the year, particles throughout the water column are available to D. r. bugenis, and differential near-bottom depletion of food resources does not occur. Also, because most of the bottom in the southern basin of Lake Michigan is soft (mud/sand) with little reef structure, and because the mussel population occurs as a single layer, water column particles would be transported effectively to the entire mussel population, unlike in other regions of the Great Lakes where bottom reefs exist (Ackerman et al., 2001). Additionally, the "profunda" phenotype of D. r. bugensis, which is the dominant phenotype found throughout Lake Michigan, has an incurrent siphon that is much longer than that of $D$. polymorpha or the shallow phenotype of $D$. r. bugenis. Thus, this phenotype has better access to the water column regardless of its position relative to other mussels. Third, calculated clearance rates of $D$. r. bugensis often equaled or exceeded phytoplankton growth rates, demonstrating their ability to reduce/ control phytoplankton abundance. Specifically, Vanderploeg et al. (2010) determined clearance rates for the profunda morph of $D$. $r$. bugensis in a series of experiments performed at low temperature and with natural seston. In 2008 the fraction of water column cleared by $D$. $r$. bugensis exceeded the phytoplankton growth rate in several depth regions in Lake Michigan, and in the $30-50 \mathrm{~m}$ zone the clearance rate exceeded the phytoplankton growth rate by a factor of 5. Fourth, likely alternative explanations for the recent changes, such as phosphorus load reductions, increased zooplankton grazing, and climate change cannot account for the observed temporal and spatial patterns (Fahnenstiel et al., 2010; Mida et al., 2010).

The mussel population in the offshore region is only in the initial stages of expansion (Nalepa et al., 2010), so the widespread changes observed in the offshore during spring may be surprising. Yet during the late winter/spring isothermal mixing period, observed currents are near optimal for Dreissena filtering and these currents can transport mussel-impacted water kilometers away from mussel populations. During this period when wind events are significant and currents can be maximal, vertically uniform currents are typically 4-5 cm/s in the southern basin (Beletsky and Schwab, 2001). At the NOAA 110-m site where Fahnenstiel et al. (2010) documented large changes in phytoplankton, near-bottom current speeds in February to May 1995 were typically between 2 and $12 \mathrm{~cm} / \mathrm{s}$ (N. Hawley, unpublished data). These currents are optimal for mussel filtering; clearance rates for $D$. $r$. bugensis were positively correlated with current speed up to a velocity of approximately $9 \mathrm{~cm} / \mathrm{s}$ and decreased at current speeds $>20 \mathrm{~cm} / \mathrm{s}$ (Ackerman, 1999). Also, water in the vicinity of mussel beds would typically move an average of $4 \mathrm{~km} / \mathrm{d}$ in the winter/spring period. Thus, in the time it would take phytoplankton biomass to double (growth rate ca. 0.06-0.10 d-1; G. Fahnenstiel, unpublished data) water could move over 20 kilometers. Vanderploeg et al. (2010) noted the possibility of mussels in 30-50 m region affecting phytoplankton abundance in deeper water regions $(>50 \mathrm{~m})$ and called it the "mid-depth sink". As Dreissena colonize most of Lake Michigan, it is important to recognize that mussel 
impacts can extend significant vertical and horizontal distances. The nearshore shunt described by Hecky et al. (2004) is one example of spatial coupling of Dreissena impacts.

The changes in water quality and primary producers noted in the first part of this special section are profound and have important ramifications for our present understanding of Lake Michigan. As noted in Mida et al. (2010), the pelagic region of southern Lake Michigan is now relatively similar to the pelagic region of Lake Superior, not only in terms of phosphorus concentrations but also in terms of primary production, phytoplankton abundance, and seasonal nutrient depletion. These dramatic changes have contributed to the oligotrophication of the pelagic region and the entire lake as well. The extent of this oligotrophication may depend on the definition of eutrophication, whether it is based on nutrient delivery (Smith et al., 1999) or primary production (Wetzel, 2001). Phytoplankton primary production has decreased in southern Lake Michigan (Fahnenstiel et al., 2010). Typically in shallow bays and regions in the Great Lakes (i.e., Saginaw Bay), decreased phytoplankton productivity from dreissenid filtering can be compensated by an increase in benthic productivity due to increased light transmittance and benthic nutrient recycling (Fahnenstiel et al., 1995). However, because only a small area of southern Lake Michigan can support significant benthic algal production, it is unlikely that an increase in benthic algal production will compensate for the decreased pelagic production. Therefore, lake-wide primary productivity has likely decreased substantially in the last 5 years. Regardless of the decrease/shift in primary production in Lake Michigan, it is important to note that the delivery or loading of nutrients to Lake Michigan has also decreased (Mida et al., 2010). The present decrease in production is simply greater and more abrupt than that due to reductions in the delivery/loading of nutrients to the system, and this represents the Dreissena effect.

This reengineering of Lake Michigan will change how it responds to additional anthropogenic influences and must be considered in future management decisions. One example is the recent oligotrophication of the offshore region and the management goal of meeting IJC target P loads and concentrations. As shown by Mida et al. (2010), both phosphorus loads and concentrations in the offshore region are now well below IJC targets, $5600 \mathrm{mt} / \mathrm{y}$ and $7 \mu \mathrm{g} / \mathrm{L}$, respectively. (see International Joint Commission, IJC, 1989). However, phosphorus dynamics have changed considerably in this post-dreissenid era (Hecky et al., 2004), and management strategies, including IJC target loads, may need to reflect these changes. Recent increases in Cladophora biomass in nearshore areas (depths $<11 \mathrm{~m}$ ) may be contributing to increases in water-borne pathogens and beach closures (Ishii et al., 2006). Further reductions in phosphorus loading are likely needed to reduce these nearshore Cladophora blooms and associated adverse outcomes (Tomlinson et al., 2010).

The final three papers in this special issue examine the abundance and dynamics of important invertebrates in the pelagic region; two indigenous species, Mysis relicta and Leptodora kindtii, and two nonindigenous species, Bythotrephes longimanus and Cercopagis pengoi. Given the precipitous decline of the benthic amphipod Diporeia, (Nalepa et al., 2009) there are questions about the health of Mysis populations because both of these organisms are heavily fed upon by forage fish. In the first paper, Pothoven et al. (2010) noted that 20072008 Mysis abundance was lower than in 1995-2002, declining 70\% at the $110-\mathrm{m}$ offshore site. This could be related to a reduction in food availability due to the recent disappearance of the spring diatom bloom (Fahnenstiel et al., 2010) and/or to an increase in fish predation despite lower fish abundance. Examining the abundance of three key predatory cladocerans, Cavaletto et al. (2010) showed the dominance of two non-indigenous species, Bythotrephes and Cercopagis, with Bythotrephes the most abundant predatory cladoceran in the offshore region, and Cercopagis the most abundant in the nearshore. A bioenergetics model was applied to Bythotrephes to determine its daily prey demands (Yurista et al., 2010). Bythotrephes consumption needs varied seasonally with an early peak in August followed by another peak in October and no trends in annual consumption were noted for a 10-year period (1994-2003). This suggests that the declines in crustacean zooplankton abundance in the last decade (Kerfoot et al., 2010; Pothoven et al., 2010) were not caused by changes in Bythotrephes predation.

The dominance of non-indigenous invertebrates in both the pelagic and benthic regions of Lake Michigan also has implications for future fisheries management. While Dreissena influence on fish populations is less clear than for phytoplankton, present fish production in Lake Michigan is likely affected by Dreissena populations. For example, the condition of two abundant planktivores, alewife Alosa pseudoharengus and lake whitefish Coregonus clupeaformis, has declined since dreissenids became abundant (Pothoven et al., 2001; Madenjian et al., 2006). Moreover, Mysis relicta density is now low at a time of low fish predation (Pothoven et al., 2010), and the question of whether Mysis populations are sustainable with increased fish predation has implications for future fisheries. A major consideration in the post-Dreissena period is whether present fisheries management goals based on a pelagic dominated system and historical food webs are realistic and sustainable.

Based on the long-term observations and experiments presented in the papers of this issue, it is apparent that recent, unprecedented changes in the lower food web of southern Lake Michigan can be attributed to the increased abundance and spatial expansion of $D . r$. bugensis. Many observed changes were similar to those resulting from the initial expansion of $D$. polymorpha in the shallow nearshore regions of the Great Lakes (i.e., decreased chlorophyll and primary production, increased water clarity, decoupling of chlorophyll from nutrient loads, etc.). Yet given the habitat, the observed changes are unique in that they demonstrate a strong vertical connection between mussel filtering activities and the extensive pelagic environment found in deep, offshore regions during a major portion of the year. Direct and indirect impacts were far-reaching, as evidenced by the loss of the spring diatom bloom and the decline of Mysis. Changes in the pelagic food web are relatively recent, and the long term, more permanent state may be quite different as the mussel population stabilizes and likely declines and the pelagic system adjusts accordingly. Presently, the D. r. bugensis population in southern Lake Michigan continues to rapidly expand at depths $>50 \mathrm{~m}$, even though potential food resources have declined to historically low levels. The future state of the lower food web is difficult to predict, mainly because temporal trends of dreissenid populations in deep, continuously cold, low food environments are unknown. Thus, while consistent long-term monitoring in the offshore region of the lake has documented some major, unexpected shifts in the lower food web, continued monitoring is needed to further define the changes certain to occur.

\section{Acknowledgments}

This is NOAA/GLERL contribution \#1564.

\section{References}

Ackerman, J.D., 1999. Effect of velocity on the filter feeding of dreissenid mussels (Dreissena polymorpha and Dreissena bugensis): implications for trophic dynamics. Can. J. Fish. Aquat. Sci. 56, 1551-1561.

Ackerman, J.D., Loewen, M.R., Hamblin, P.F., 2001. Benthic-pelagic coupling over a zebra mussel reef in western Lake Erie. Limnol. Oceanogr. 46, 892-904.

Beletsky, D., Schwab, D.J., 2001. Modeling circulation and thermal structure in Lake Michigan; Annual cycle and interannual variability. J. Geophys. Res. 106, 19745-19771.

Cavaletto, J.R., Vanderploeg, H.A., Pichlová-Ptáčníková, R., Pothoven, S.A., Liebig, J.R., Fahnenstiel, G.L., 2010. Temporal and spatial separation allow coexistence of predatory cladocerans: Leptodora kindtii, Bythotrephes longimanus and Cercopagis pengoi, in southeastern Lake Michigan. J. Great Lakes Res. 36 (Supplement 3), 65-73. 
Fahnenstiel, G.L., Bridgeman, T.B., Lang, G.A., McCormick, M.J., Nalepa, T.F., 1995. Phytoplankton productivity in Saginaw Bay, Lake Huron: effects of zebra mussel (Dreissena polymorpha) colonization. J. Great Lakes Res. 21, 465-475.

Fahnenstiel, G.L., Pothoven, S., Nalepa, T., Vanderploeg, H., Klarer, D., Scavia, D., 2010. Recent changes in primary production and phytoplankton in the offshore region of southeastern Lake Michigan. J. Great Lakes Res. 36 (Supplement 3), 20-29.

Gardner, W.S., Quigley, M.A., Fahnenstiel, G.L., Scavia, D., Frez, W.A., 1990. Pontoporeia hoyi-a direct trophic link between spring diatoms and fish in Lake Michigan. In: Tilzer, M.M., Serruya, C. (Eds.), Large Lakes: structural and functional properties. Springer, pp. 632-644.

Hecky, R.E., Smith, R.E.H., Barton, D.R., Guildford, S.J., Taylor, W.D., Charlton, M.N., Howell, T., 2004. The nearshore phosphorus shunt: a consequence of ecosystem engineering by dreissenids in the Laurentian Great Lakes. Can. J. Fish. Aquat. Sci. 61, 1285-1293.

Hobbie, J.E., Carpenter, S.R., Grimm, N.B., Gosz, J.R., Seastedt, T.R., 2003. The U.S. long term ecological research program. Bioscience 53, 21-32.

International Joint Commission (IJC), 1989. Report on Great Lakes Water Quality. Great Lakes Water Quality Board report to IJC, Windsor, Ontario.

Ishii, S., Yan, T., Shively, D.A., Byappanahalli, M.N., Whitman, R.L., Sadowsky, M.J., 2006. Cladophora (Chlorophyta) spp. harbor human bacterial pathogens in nearshore water of Lake Michigan. Appl. Env. Microb. 72, 4545-4553.

Kerfoot, W.C., Budd, J.W., Green, S.A., Cotner, J.B., Biddanda, B.A., Schwab, D.J., Vanderploeg, H.A., 2008. Doughnut in the desert: late-winter production pulse in southern Lake Michigan. Limnol. Oceanogr. 53, 589-604.

Kerfoot, W.C., Yousef, F., Green, S.A., Budd, J.W., Schwab, D.J., Vanderploeg, H.A., 2010. Approaching storm: disappearing winter bloom in Lake Michigan. J. Great Lakes Res. 36 (Supplement 3), 30-41.

Madenjian, C.P., Fahnenstiel, G.L., Johengen, T.H., Nalepa, T.F., Vanderploeg, H.A., Fleischer, G.W., Schneeberger, P.J., Benjamin, D.M., Smith, E.B., Bence, J.R., Rutherford, E.S., Lavis, D.S., Robertson, D.M., Jude, D.J., Ebener, M.P., 2002. Dynamics of the Lake Michigan food web, 1970-2000. Can. J. Fish. Aquat. Sci. 59, 736-753.

Madenjian, C.P., Pothoven, S.A., Dettmers, J.M., Holuszko, J.D., 2006. Changes in seasonal energy dynamics of alewife (Alosa pseudoharengus) in Lake Michigan after invasion of dreissenid mussels. Can. J. Fish. Aquat. Sci. 63, 891-902.

Magnuson, J.J., 1990. Long-term ecological research and the invisible present. Bioscience 40, 495-501.

Mida, J.L., Scavia, D., Fahnenstiel, G.L., Pothoven, S.A., Vanderploeg, H.A., Dolan, D.M., 2010. Long-term and recent changes in southern Lake Michigan water quality with implications for present trophic status. J. Great Lakes Res. 36 (Supplement 3), 42-49.
Mills, E.L., Leach, J.H., Carlton, J.T., Secor, C.L., 1993. Exotic species in the Great Lakes: a history of biotic crises and anthropogenic introductions. J. Great Lakes Res. 19, $1-54$

Nalepa, T.F., Fahnenstiel, G.L., 1995. Dreissena polymorpha in the Saginaw Bay. Lake Huron Ecosystem: Overview and Perspective. J. Great Lakes Res. 21, 411-416.

Nalepa, T.F., Fanslow, D.L., Lang, G.A., 2009. Transformation of the offshore benthic community in Lake Michigan: recent shift from the native amphipod Diporeia spp. to the invasive mussel Dreissena rostriformis bugenis. Freshw. Biol. 54, 466-479.

Nalepa, T.P., Fanslow, D.L., Pothoven, S.A., 2010. Recent changes in density, biomass recruitment, size structure, and nutritional state of Dreissena populations in southern Lake Michigan. J. Great Lakes Res. 36 (Supplement 3), 5-19.

Pothoven, S.A., Nalepa, T.F., Schneeberger, P.J., Brandt, S.B., 2001. Changes in diet and body composition of lake whitefish in southern Lake Michigan associated with changes in benthos. N. Am. J. Fish. Manage. 21, 876-883.

Pothoven, S.A., Fahnenstiel, G.L., Vanderploeg, H.A., 2010. Temporal trends in Mysis relicta abundance, production and life-history characteristics in southeastern Lake Michigan. J. Great Lakes Res. 36 (Supplement 3), 60-64.

Scavia, D., Fahnenstiel, G.L., Evans, M.S., Jude, D.J., Lehman, J.T., 1986. Influence of salmonid predation and weather on long-term water quality trends in Lake Michigan. Can. J. Fish. Aquat. Sci. 43, 435-443.

Smith, V.H., Tilman, G.D., Nekola, J.C., 1999. Eutrophication: impacts of excess nutrient inputs on freshwater, marine and terrestrial ecosystems. Env. Poll. 100, 179-196.

Tomlinson, L.M., Auer, M.T., Bootsma, H.A., Owens, E.M., 2010. The Great Lakes Cladophora model: development, testing and application to Lake Michigan. J. Great Lakes Res. 36, 287-297.

Vanderploeg, H.A., Nalepa, T.F., Jude, D.J., Mills, E.L., Holeck, K.T., Liebig, J.R., Grigorovich, I.A., Ojaveer, H., 2002. Dispersal and emerging ecological impacts of Ponto-Caspian species in the Laurentian Great Lakes. Can. J. Fish. Aquat. Sci. 59, 1209-1228.

Vanderploeg, H.A., Liebig, J.R., Nalepa, T.F., Fahnenstiel, G.L., Pothoven, S.A., 2010. Dreissena and the disappearance of the spring phytoplankton bloom in Lake Michigan. J. Great Lakes Res. 36 (Supplement 3), 50-59.

Wetzel, R.G., 2001. Limnology: Lake and River Ecosytems. Academic Press, San Diego, CA.

Yurista, P., Vanderploeg, H.A, Liebig, J.R. Cavaletto, J.F., 2010. Lake Michigan Bythotrephes prey consumption estimates for 1994-2003 using a temperature and size corrected bioenergetic model. J. Great Lakes Res. 36 (Supplement 3) 74-82. 